NASA/TM-2007-215008

ARL-TR-4124
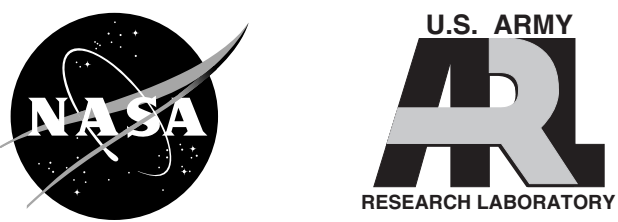

\title{
Wear of Spur Gears Having a Dithering Motion and Lubricated With a Perfluorinated Polyether Grease
}

Timothy Krantz

U.S. Army Research Laboratory, Glenn Research Center, Cleveland, Ohio

Fred Oswald

Glenn Research Center, Cleveland, Ohio

Robert Handschuh

U.S. Army Research Laboratory, Glenn Research Center, Cleveland, Ohio 


\section{NASA STI Program . . . in Profile}

Since its founding, NASA has been dedicated to the advancement of aeronautics and space science. The NASA Scientific and Technical Information (STI) program plays a key part in helping NASA maintain this important role.

The NASA STI Program operates under the auspices of the Agency Chief Information Officer. It collects, organizes, provides for archiving, and disseminates NASA's STI. The NASA STI program provides access to the NASA Aeronautics and Space Database and its public interface, the NASA Technical Reports Server, thus providing one of the largest collections of aeronautical and space science STI in the world. Results are published in both non-NASA channels and by NASA in the NASA STI Report Series, which includes the following report types:

- TECHNICAL PUBLICATION. Reports of completed research or a major significant phase of research that present the results of NASA programs and include extensive data or theoretical analysis. Includes compilations of significant scientific and technical data and information deemed to be of continuing reference value. NASA counterpart of peer-reviewed formal professional papers but has less stringent limitations on manuscript length and extent of graphic presentations.

- TECHNICAL MEMORANDUM. Scientific and technical findings that are preliminary or of specialized interest, e.g., quick release reports, working papers, and bibliographies that contain minimal annotation. Does not contain extensive analysis.

- CONTRACTOR REPORT. Scientific and technical findings by NASA-sponsored contractors and grantees.
- CONFERENCE PUBLICATION. Collected papers from scientific and technical conferences, symposia, seminars, or other meetings sponsored or cosponsored by NASA.

- SPECIAL PUBLICATION. Scientific, technical, or historical information from NASA programs, projects, and missions, often concerned with subjects having substantial public interest.

- TECHNICAL TRANSLATION. Englishlanguage translations of foreign scientific and technical material pertinent to NASA's mission.

Specialized services also include creating custom thesauri, building customized databases, organizing and publishing research results.

For more information about the NASA STI program, see the following:

- Access the NASA STI program home page at http://www.sti.nasa.gov

- E-mail your question via the Internet to help@sti.nasa.gov

- Fax your question to the NASA STI Help Desk at 301-621-0134

- Telephone the NASA STI Help Desk at 301-621-0390

- Write to: NASA Center for AeroSpace Information (CASI) 7115 Standard Drive Hanover, MD 21076-1320 
NASA/TM-2007-215008

ARL-TR-4124
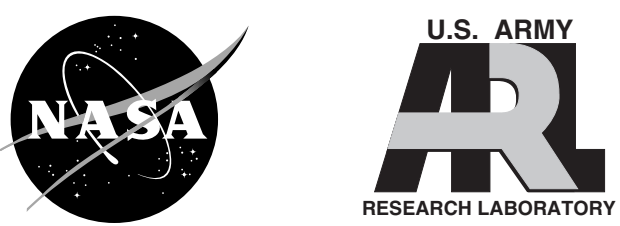

\section{Wear of Spur Gears Having a Dithering Motion and Lubricated With a Perfluorinated Polyether Grease}

Timothy Krantz

U.S. Army Research Laboratory, Glenn Research Center, Cleveland, Ohio

Fred Oswald

Glenn Research Center, Cleveland, Ohio

Robert Handschuh

U.S. Army Research Laboratory, Glenn Research Center, Cleveland, Ohio

Prepared for the

International Design Engineering Technical Conferences and Computers and Information in Engineering Conference

sponsored by the American Society of Mechanical Engineers

Las Vegas, Nevada, September 4-7, 2007

National Aeronautics and

Space Administration

Glenn Research Center

Cleveland, Ohio 44135 
Level of Review: This material has been technically reviewed by technical management.

Available from

NASA Center for Aerospace Information

7115 Standard Drive

Hanover, MD 21076-1320
National Technical Information Service 5285 Port Royal Road Springfield, VA 22161

Available electronically at http://gltrs.grc.nasa.gov 


\title{
Wear of Spur Gears Having a Dithering Motion and Lubricated With a Perfluorinated Polyether Grease
}

\author{
Timothy Krantz \\ U.S. Army Research Laboratory \\ Glenn Research Center \\ Cleveland, Ohio 44135 \\ Fred Oswald \\ National Aeronautics and Space Administration \\ Glenn Research Center \\ Cleveland, Ohio 44135 \\ Robert Handschuh \\ U.S. Army Research Laboratory \\ Glenn Research Center \\ Cleveland, Ohio 44135
}

\begin{abstract}
Gear contact surface wear is one of the important failure modes for gear systems. Dedicated experiments are required to enable precise evaluations of gear wear for a particular application. The application of interest for this study required evaluation of wear of gears lubricated with a grade 2 perfluorinated polyether grease and having a dithering (rotation reversal) motion. Experiments were conducted using spur gears made from AISI 9310 steel. Wear was measured using a profilometer at test intervals encompassing 10,000 to 80,000 cycles of dithering motion. The test load level was 1.1 GPa maximum Hertz contact stress at the pitch-line. The trend of total wear as a function of test cycles was linear, and the wear depth rate was approximately $1.2 \mathrm{~nm}$ maximum wear depth per gear dithering cycle. The observed wear rate was about 600 times greater than the wear rate for the same gears operated at high speed and lubricated with oil.
\end{abstract}

\section{Introduction}

Gear contact surface wear is one of the important failure modes in gear systems. Wear and the associated material loss can lead to structural failure (gear tooth fracture). Wear can also lead to changes in vibration and noise behavior (ref. 1 to 3). In addition, wear can change the patterns of gear contact such that the altered load distributions and contact stresses will accelerate the occurrence of other failure modes such as pitting and scoring (ref. 4). Gear wear debris can also be detrimental to the performance of bearings or other components of a drive system (ref. 5).

The study of wear is becoming one of the emerging areas of gear research. A number of recent wear modeling efforts (refs. 6 to 10) form a solid foundation for studying gear wear. The common thread to these studies is that all use the well-known Archard's wear model (ref. 11) in conjunction with a gear contact model and relative sliding calculations. Archard's wear equation can be expressed for a local point on one of the contacting gear surfaces as $d h / d s=k P$ where $k$ is an experimentally determined wear coefficient, $h$ is the wear depth accumulated, $P$ is the contact pressure, and $s$ is the sliding distance between the mating surfaces at the point of interest. From this equation, to calculate the wear depth $h$, the contact pressure $P$ and the sliding distance $s$ must be determined. Flodin and Andersson (refs. 6 to 8) and Bajpai et al. (ref. 9) proposed wear models for spur and helical gears, and the focus was to determine $P$ and $s$. The tooth contact pressures $P$ were computed in these models using either simplified Hertzian contact (refs. 6 to 8) or boundary element (ref. 9) formulations under quasi-static conditions. Sliding distance $s$ calculations were determined from gearing kinematics, and Archard's wear model (ref. 11) was used with an empirical wear coefficient to compute the surface wear distribution.

Perhaps the most significant shortcoming of the gear wear prediction models discussed above is that they consider wear depth to be a function of only two parameters, contact pressure, $P$ and sliding distance, $s$. All other influences, such as surface material, surface roughness and lubrication at the contact interface, are all accounted for by the wear coefficient $k$ (ref. 12). When all of the parameters including lubricant type, temperature, flow rate, gear material composition, surface topography, and surface hardness are consistent, then it is possible to define $\mathrm{K}$ using a small number of controlled experiments (ref. 9). However, if all of the stated properties are not consistent, then determining a wear rate coefficient is a challenging task. In addition, the influence of such parameters on wear cannot be described by these models. As such, dedicated experiments are often required to enable accurate predictions of gear wear for a particular application.

Perfluorinated polyether greases are commonly used for space mechanisms. Discussions in support of mechanism maintenance (ref. 13) have highlighted the need for data to better understand the wear and behavior of mechanical components operated using such grease. Some qualitative results of gear wear experiments were previously reported (ref. 14). To quantify wear rates for gears lubricated with 
perfluorinated polyether grade 2 grease, spur gear experiments were completed.

\section{Test Methodology}

\section{Test Rig}

The experiments were conducted using the NASA Glenn Research Center Spur Gear Fatigue Test Rigs. These test rigs have been used for more than 30 years to test oil lubricated spur gears, with emphasis on studying contact fatigue (spalling, pitting, and micropitting). The test rig, as shown in figure 1(a), uses the four-square (torque-regenerative) principle of applying test loads, and thus the motor needs to overcome only the frictional losses in the system. The test rig is belt driven using a variable speed electric motor. A schematic of the loading apparatus is shown in figure 1(b). Hydraulic oil pressure and leakage replacement flow is supplied to the load vanes through a shaft seal. As the oil pressure is increased on the load vanes located inside one of the slave gears, torque is applied to its shaft. This torque is transmitted through the test gears and back to the slave gears. In this way power is circulated, and the desired load and corresponding stress level on the test gear teeth may be obtained by adjusting the hydraulic pressure.

Figure 1 depicts the spur gear rig as has been used for tests operated at $10,000 \mathrm{rpm}$ for the purpose of evaluating the fatigue lives of oil lubricated gears. The test setup as used for the grease tests reported herein differed from the depiction of figure 1 in two important ways. Figure 1 illustrates the test gears operating with faces offset. The face-offset condition is used to concentrate the Hertz contact stress as is desired for accelerated life testing of high cycle fatigue. For the grease lubricated gear testing, the gears were operated with zero offset (full faces in contact with each other). Also, figure 1 depicts pressurized labyrinth seals on the two shafts. For the grease testing reported herein, lip seals were used on the two shafts to prevent leakage of the slave gear lubricating oil to the grease lubricated test gear section. The lip seals have been used with much success on these rigs to maintain zeroleakage even for speeds of 10,000 rpm.

For some applications, gear teeth will operate both as a driving and as a driven member depending on the motions and torques applied to the machine at any given instant. Hall et al. (ref. 13) provide an example of an actuator that operated in a dithering mode whereby a gear rotated with a back and forth motion with a nominally constant torque (fig. 2). For such operation, the gears can create wear debris on an approach path and then entrain the debris into the gear contact on the return path. For the subject experiments, the gear test rig was operated in such a dithering mode. To create the dithering motion, a four-bar linkage mechanism was attached to the drive shaft of the test rig (fig. 3). The four-bar linkage was designed to allow for adjustments to the range of motion. For the tests reported herein a full rotation of the electric motor rotated the gears through $\pm 28^{\circ}$ of rotation. This range of motion ensured that one tooth pair would operate for a full gear tooth engagement cycle for each forward and return stroke of the mechanism. The frequency of motion was $4 \mathrm{~Hz}$ (4 dithering cycles per second).
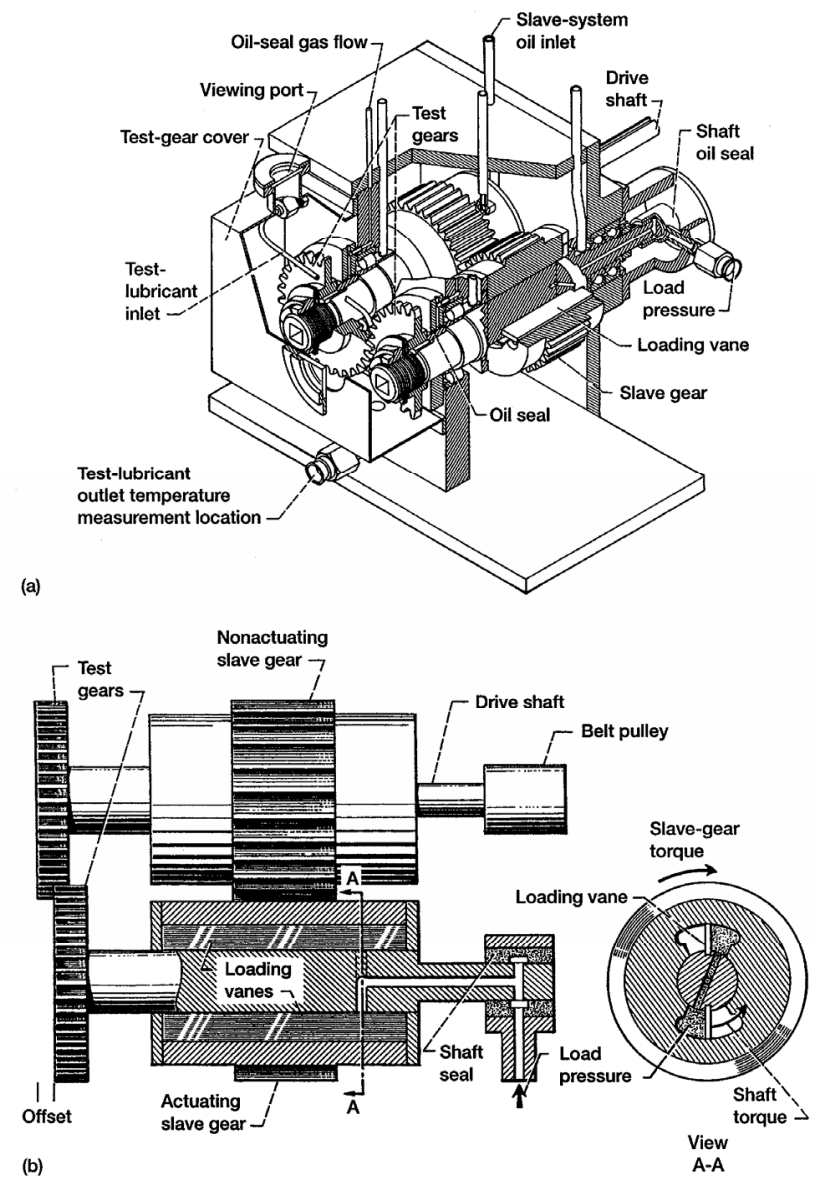

Figure 1.-NASA Glenn Research Center gear fatigue test apparatus. (a) Cutaway view. (b) Schematic view.
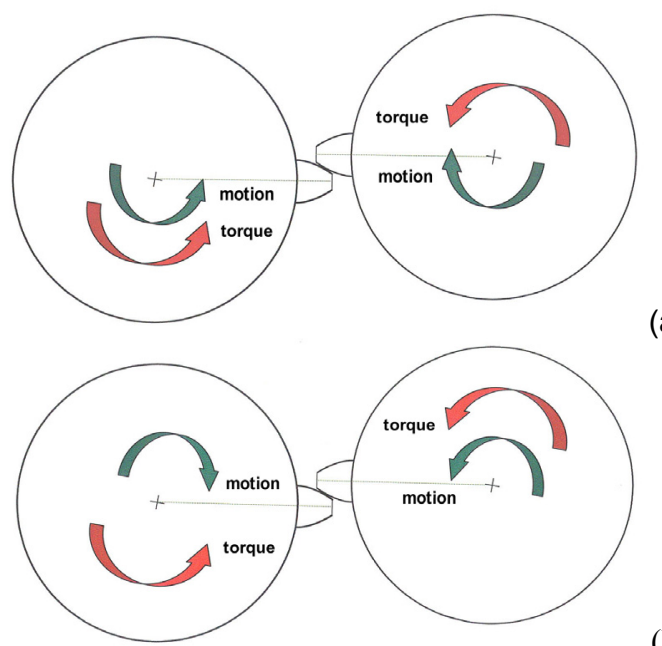

(a)

(b)

Figure 2.-Illustration of the reversal of motion and constant direction of torque used for wear testing. (a) Forward stroke of dithering motion. (b) Reverse stroke of dithering motion. 


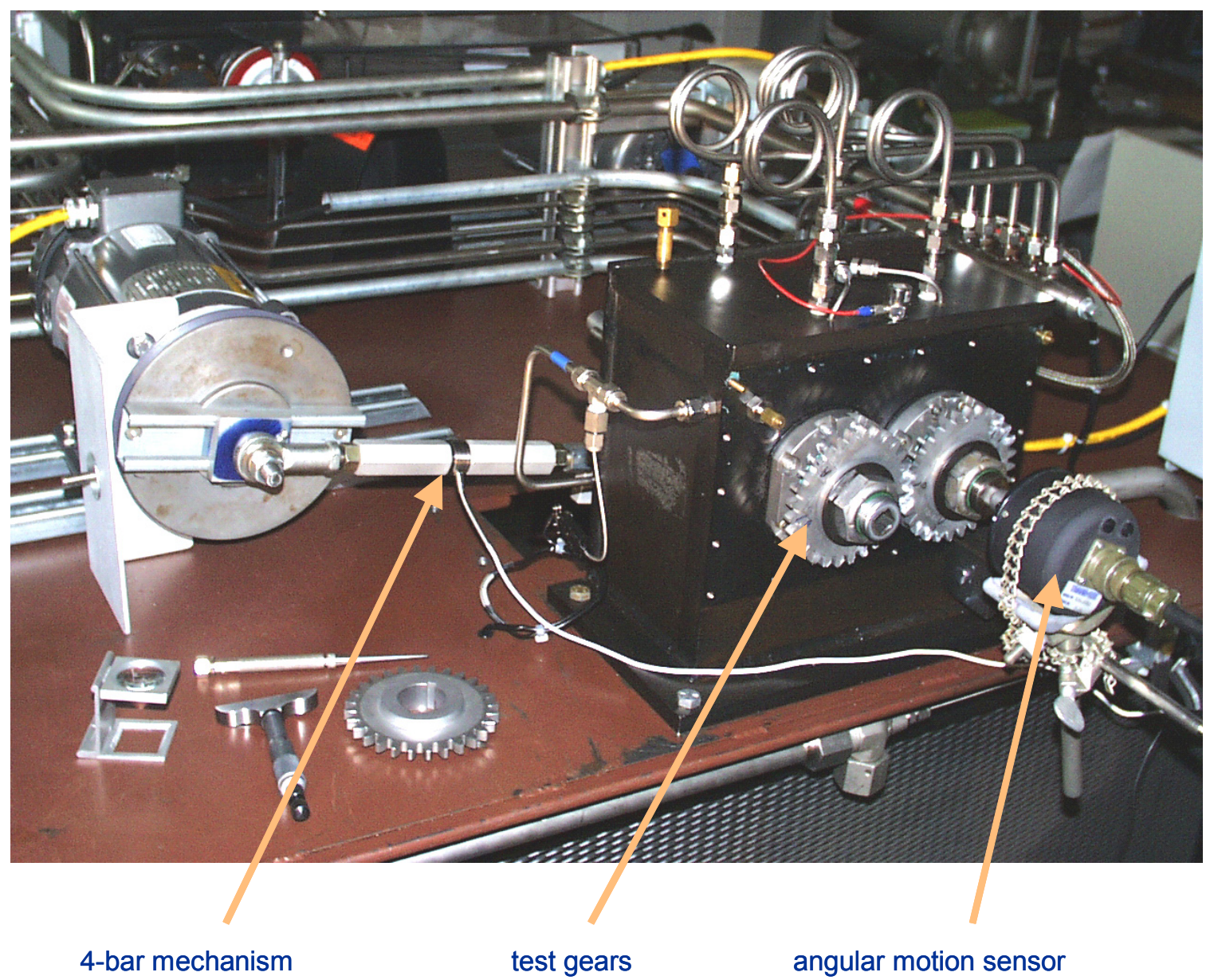

Figure 3.-Spur gear test rig configured for grease lubricated testing using a dithering motion.

\section{Test Gears and Lubricant}

The test gears used for this work were manufactured from a single lot of consumable-electrode vacuum-melted (CVM) AISI 9310 steel. The nominal chemical composition of the AISI 9310 material is given in table 1 . The gears were case carburized and heat treated according to table 2 . The nominal properties of the carburized gears were a case hardness of Rockwell C60, a case depth of $0.97 \mathrm{~mm}$ ( $0.038 \mathrm{in}$.), and a core hardness of Rockwell C38. The dimensions for the test gears are given in table 3 . The gear pitch diameter was $89 \mathrm{~mm}$ ( $3.5 \mathrm{in}$.), and the tooth form was a $20^{\circ}$ involute profile modified to provide a tip relief of $0.013 \mathrm{~mm}(0.0005 \mathrm{in}$.) starting at the highest point of single tooth contact. The gears have zero lead crowning but do have a nominal $0.13-\mathrm{mm}-$ (0.005-in.-) radius edge break at the tips and sides of the teeth. The gear tooth surface finish after final grinding was specified as a maximum of $0.406 \mu \mathrm{m}(16 \mu \mathrm{in}$.) rms. Tolerances for the gear geometries were specified to meet AGMA (American Gear Manufacturers Association) quality level class 11. Gears were lubricated using a single container of grade 2 perfluorinated polyether grease. The grease is qualified for use on space mechanisms.

TABLE 1.-NOMINAL CHEMICAL COMPOSITION OF AISI 9310 GEAR MATERIAL

\begin{tabular}{|l|c|}
\hline Element & wt $\%$ \\
\hline Carbon & 0.10 \\
\hline Nickel & 3.22 \\
\hline Chromium & 1.21 \\
\hline Molybdenum & 0.12 \\
\hline Copper & 0.13 \\
\hline Manganese & 0.63 \\
\hline Silicon & 0.27 \\
\hline Sulfur & 0.005 \\
\hline Phosphorous & 0.005 \\
\hline Iron & balance \\
\hline
\end{tabular}


TABLE 2.-HEAT TREATMENT FOR AISI 9310 GEARS

\begin{tabular}{|c|c|c|c|c|}
\hline \multirow[t]{2}{*}{ Step } & \multirow[t]{2}{*}{ Process } & \multicolumn{2}{|c|}{ Temperature } & \multirow[t]{2}{*}{ Time, hr } \\
\hline & & K & ${ }^{\circ} \mathrm{F}$ & \\
\hline 1 & Preheat in air & - & - & - \\
\hline 2 & Carburize & 1,172 & 1,650 & 8 \\
\hline 3 & $\begin{array}{l}\text { Air cool to room } \\
\text { temperature }\end{array}$ & - & - & - \\
\hline 4 & Copper plate all over & - & - & - \\
\hline 5 & Reheat & 922 & 1,200 & 2.5 \\
\hline 6 & $\begin{array}{l}\text { Air cool to room } \\
\text { temperature }\end{array}$ & - & - & - \\
\hline 7 & Austentize & 1,117 & 1,550 & 2.5 \\
\hline 8 & Oil quench & - & - & - \\
\hline 9 & Subzero cool & 180 & -120 & 3.5 \\
\hline 10 & Double temper & 450 & 350 & 2 each \\
\hline 11 & Finish grind & - & - & - \\
\hline 12 & Stress relieve & 450 & 350 & 2 \\
\hline
\end{tabular}

TABLE 3.- SPUR GEAR DATA

[Gear tolerance per AGMS class 11]

\begin{tabular}{|lr|}
\hline Number of teeth & 28 \\
\hline Module, mm & 3.175 \\
\hline Diametral pitch & 8 \\
\hline Circular pitch, mm (in.) & $9.975(0.3927)$ \\
\hline Whole depth, mm (in.) & $7.62(0.300)$ \\
\hline Addendum, mm (in.) & $3.18(.125)$ \\
\hline $\begin{array}{l}\text { Chordal tooth thickness } \\
\text { reference, mm (in.) }\end{array}$ & $4.85(0.191)$ \\
\hline Tooth width, mm (in.) & $6.35(0.25)$ \\
\hline Pressure angle, deg. & $88.90(3.500)$ \\
\hline Pitch diameter, mm (in.) & $95.25(3.750)$ \\
\hline Outside diameter, mm (in.) & 1.02 to 1.52 \\
\hline Root fillet, mm (in.) & $(0.04$ to 0.06$)$ \\
\hline $\begin{array}{l}\text { Measurement over pins, mm } \\
\text { (in.) }\end{array}$ & 96.03 to 96.30 \\
\hline Pin diameter, mm (in.) & $(3.7807$ to 3.7915$)$ \\
\hline Backlash reference, mm (in.) & $5.49(0.216)$ \\
\hline Tip relief, mm (in.) & $0.254(0.010)$ \\
\hline
\end{tabular}

\section{Test Procedure}

The test gears were cleaned to remove a rust-preventative preservative, assembled on the test rig, and grease was applied. The gears were tested with the tooth faces fully engaged (the faces were not offset as depicted in Fig. 1). Tests were run at a frequency of 4 full dither cycles per second. All tests were conducted with a hydraulic pressure of $1.72 \mathrm{MPa}$
(250 psi) applied to the loading device. The torque produced for such a hydraulic pressure was verified both before and after testing to be $68 \mathrm{~N}-\mathrm{m}(51 \mathrm{ft}-\mathrm{lb})$. The applied torque resulted in a contact condition of $1.1 \mathrm{GPa}(160 \mathrm{ksi})$ maximum Hertz contact stress at the pitch-line. The Hertz stress just stated is an idealized stress index assuming static equilibrium, gears meshing at the pitch-point position, perfectly smooth surfaces, and an even load distribution across the measured active face width.

The active face width was measured using a profilometer tracing in the lead direction. The profile trace was used to determine the effect of the edge break radius on the active face width. Three pairs of gear teeth were tested. For each tooth pair, the testing was stopped three times to make tooth profile measurements. The test matrix of running times (dithering cycles) is listed in table 4. Prior to measuring the tooth profiles, grease and wear debris were removed from the teeth using soft-tipped tools. Chemicals were not used to assist the removal of the grease and wear debris to avoid contamination of the tooth surface that was to undergo additional testing.

\section{TABLE 4. - TEST MATRIX FOR SPUR GEAR WEAR TESTING SHOWING CYCLE COUNT WHERE TESTING WAS STOPPED FOR WEAR MEASUREMENTS}

\begin{tabular}{|c|c|}
\hline Tooth Pair & $\begin{array}{c}\text { Accumulated Number } \\
\text { of Dithering Cycles }\end{array}$ \\
\hline B & 5,000 \\
\hline B & 10,000 \\
\hline C & 10,000 \\
\hline A & 20,000 \\
\hline C & 20,000 \\
\hline A & 40,000 \\
\hline B & 40,000 \\
\hline A & 80,000 \\
\hline C & 80,000 \\
\hline
\end{tabular}

\section{Measurement of Wear}

Wear was determined by measuring the gear tooth profiles prior to testing, then again measuring the tooth profiles after testing, and comparing the data. The teeth were measured using a stylus profilometer with a small-bore diamond-tipped stylus having a $2 \mu \mathrm{m} 90^{\circ}$ tip. Three traces were obtained for each gear for each test condition, the three traces at nominally equal spacing across the face width. The profilometery data were not filtered (other than the mechanical filtering inherent to the stylus-type measurement technique). The profiles measured were of $7.2 \mathrm{~mm}$ length, tracing from below the true involute form radius in the root area of the gear to beyond the tip and across the topland of the tooth. The concept of the wear measurement procedure involved overlaying traces of the new gear and worn gear, with any differences attributed to wear. To assist with the overlaying procedure, the gears were mounted on the measuring machine using a fixture employing 
a gear rack (fig. 4). The fixture was used to fix the orientation of the gear relative to the measuring machine coordinate axes. With such a fixture, profiles could be overlaid after translation of one trace relative to the other. Rotations of coordinate systems were not necessary. A typical set of raw data plots for a gear tooth, before and after testing, is provided in figure 5(a).

To determine wear from profilometer traces, it was necessary to first overlay the two traces and then subtract one from the other. The overlaying of traces was done using a semi-automated procedure. The first step was to visually translate the data for profile of the "worn" tooth until the plots of the two profiles were closely matched in the root and topland parts of the profiles (that is, those locations with no contact and no wear). After this initial manual operation of overlaying was completed, a computer algorithm was then used to optimize the translation of the trace. The optimization was done to minimize the sum of the squares of the distances between the nearest-neighbor datapoints on the two traces in the regions of the root and topland that were not in contact. A typical dataplot for two traces after optimizing the translation of the worn trace is provided in figure 5(b). Subtracting the "new" profile data from the "worn" profile data point by point yielded the wear of the tooth as a function of position along the tooth (fig. 5(c)).

Wear amounts were characterized and summarized as follows. For each wear profile the maximum depth of wear and the area under the wear curve (by numerical integration) were determined. The wear area can be considered as a measure of the volume of material removed per unit facewidth of the gear tooth. The wear depth and wear area data were fit to regression models. To complete the regression and accompanying statistical analysis, the data were first transformed as $\mathrm{X}=$ (number of dithering cycles) $^{1 / 2}$ and $\mathrm{Y}=$ (wear $^{1 / 2}$. Such a transformation was found to provide a regression model having $\mathrm{X}$ proportional to $\mathrm{Y}$ and having residuals with normal distributions and equal variance for all tested values of $\mathrm{X}$. Two-sided point-by-point 95 percent tolerance intervals at 95 percent statistical confidence were determined using the method of Hahn and Meeker (ref. 15).

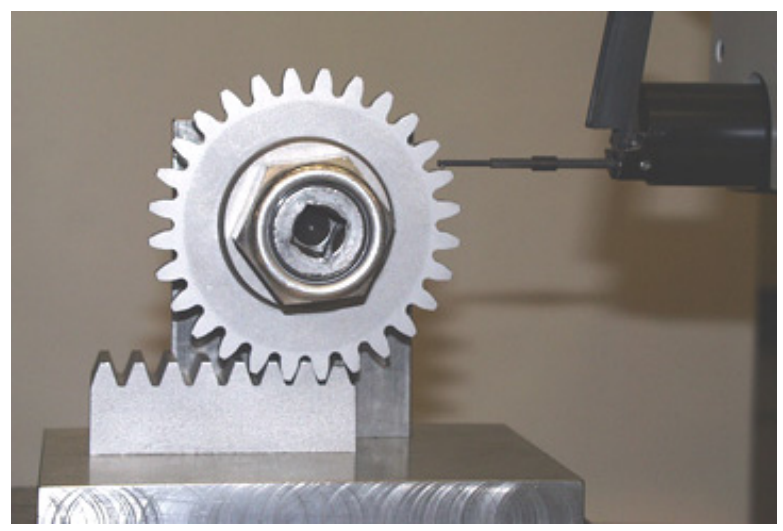

Figure 4.-Gear mounted on a profilometer using a gear rack to locate and orient the tooth.
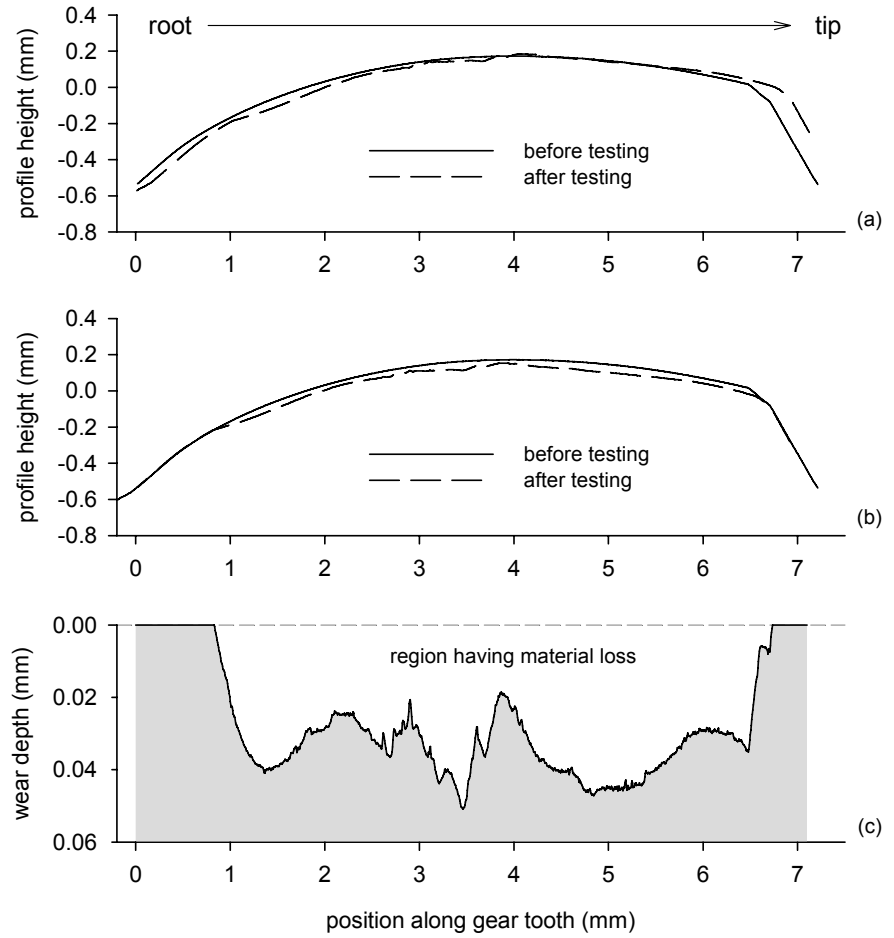

Figure 5.-Method for determining wear from profilometer data. (a) Raw traces of the profilometer data. (b) Profilometer data after $X$ and $Y$ translations of the second trace to matchup profiles in the tooth root and topland regions. (c) Wear depths as obtained by the difference of the two traces of plot (b).

\section{Test Results}

To quantify wear rates for gears lubricated with perfluorinated polyether grade 2 grease a set of spur gear experiments were completed. The wear amounts were characterized by (a) the maximum depth of wear and (b) the total volume of material removed per unit face width (termed wear area). Wear profiles for all test conditions are provided in reference 13. The gear teeth developed unique wear patterns. That is, there were significant differences in wear profile amount and shapes from one tooth to another. It is speculated that the wear patterns are determined by the detailed geometry and conditions of the mating teeth including all of form, waviness, roughness features, and hardness.

A photograph showing the typical condition of a worn tooth is provided in figure 6 . The visual appearance of the tested surface differed from tip to root, likely depending on the amounts of relative sliding. In areas of high relative sliding (toward the tip), the surface is relatively smooth. For areas of low to moderate sliding, the surface appears to have some plastic flow (rippling) and evidence of abrasive wear. Note that some wear products remained on the surface after the mild mechanical cleaning that was done prior to measurements. The visual appearance of the teeth surfaces were similar for all tests ranging from 20,000 to 80,000 total dithering cycles. 


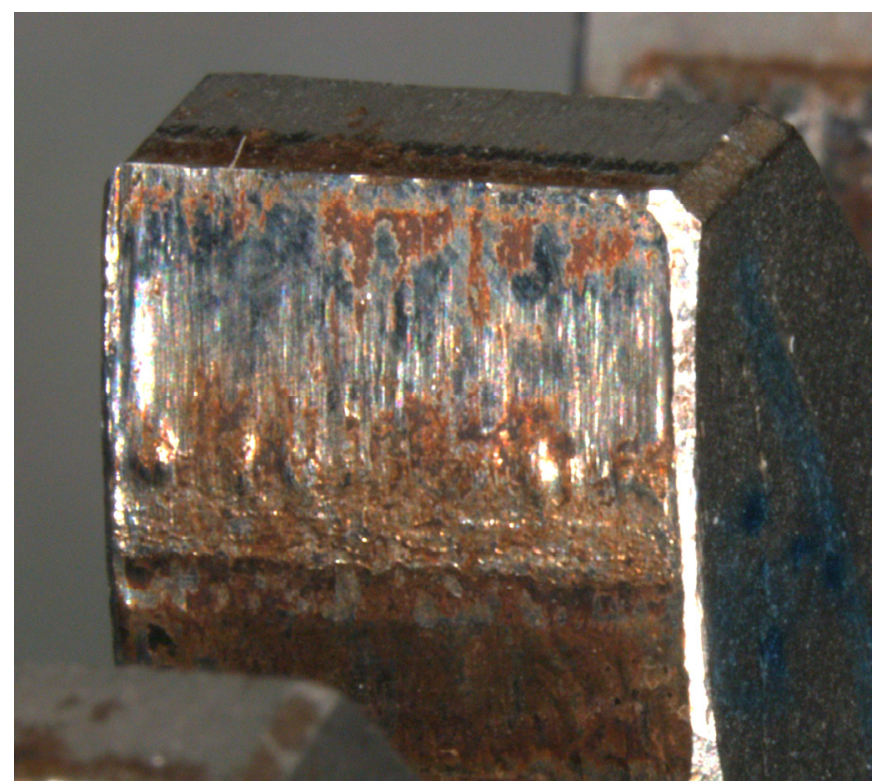

Figure 6.-The typical condition of the worn gear teeth.

The wear profiles were characterized by the maximum wear depth and by the wear areas, and the data were fit to a regression model. The wear depth data and regression results are provided in figure 7 and the wear area data and regression results are provided in figure 8 . The wear rate was approximately $1.2 \mathrm{~nm}$ maximum wear depth per gear dithering cycle. The rate of wear area removal was approximately $5 \times 10^{-6} \mathrm{~mm}^{2}$ per gear dithering cycle. Both the wear depth data and wear area data show a linear trend of wear accumulation for the full range of test cycles that were investigated. The data also shows a significant range of results for a given number of cycles. To characterize the data, two-sided point-by-point 95 percent tolerance intervals at 95 percent statistical confidence were calculated. The statistical intervals quantify the range of data one could expect for a large population of tests conducted in identical fashion. By plotting the sorted residuals of the regression models, it was verified that the assumption of a normal distribution of the residuals in the transformed domain was a reasonable assumption. The tolerance intervals are provided on the data plots of figures 7 and 8 .

\section{Discussion}

The experiments and test results characterized the wear of 8-pitch spur gears having a dithering type motion, a $1.1 \mathrm{GPa}$ (160 ksi) maximum Hertz contact stress at the pitch-line, and lubricated with a perfluorinated polyether grade 2 grease. For such test conditions the gears operate in the boundary lubrication regime, and this produced high wear rates relative to the wear rates of high speed, oil lubricated gearing. Comparing the rate of wear depth accumulation of the present experiments to the experiments of Krantz and Kahraman (ref. 10) that made use of gears having the same material and geometry, the wear rate for the grease lubricated gears of this study was on the order of 600 times greater than for oil lubricated gears operating in the mixed elastohydrodynamic lubrication regime. If such wear rates for the grease lubricated gears would not meet the application requirements, then it would be necessary to investigate component redesign, surface engineering, an improved lubricant, and/or improved antiwear additives to provide the desired performance.

A significant finding was to discover that the trend of total wear was a linear function of test cycles. For the application of this data to validate inspection and reuse criteria, it would be reasonable to project continued linear trends of field data so long as the maximum wear depths and relative percentage of case depth loss were bounded by the data of the present investigation.

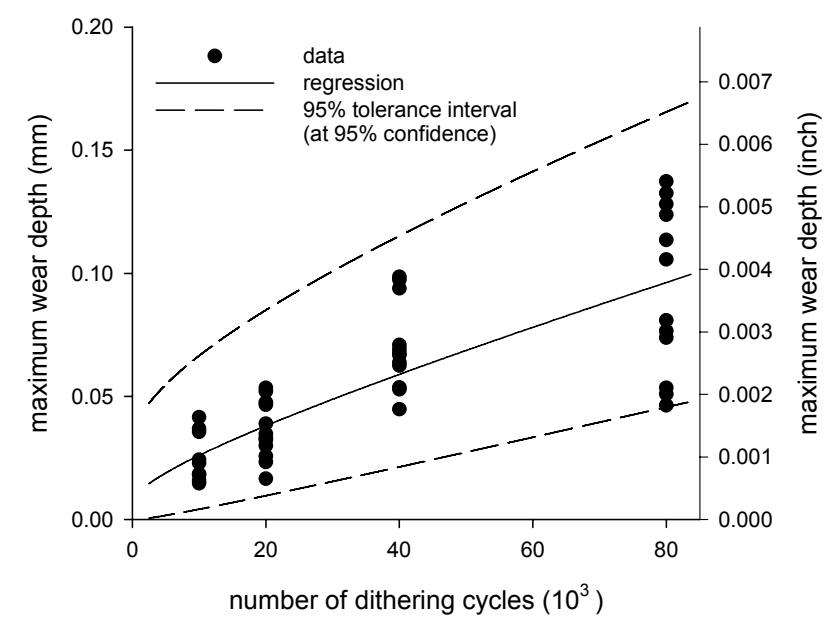

Figure 7.-Summary of maximum wear depths as a function of number of dithering cycles showing datapoints, regression model, and tolerance intervals.

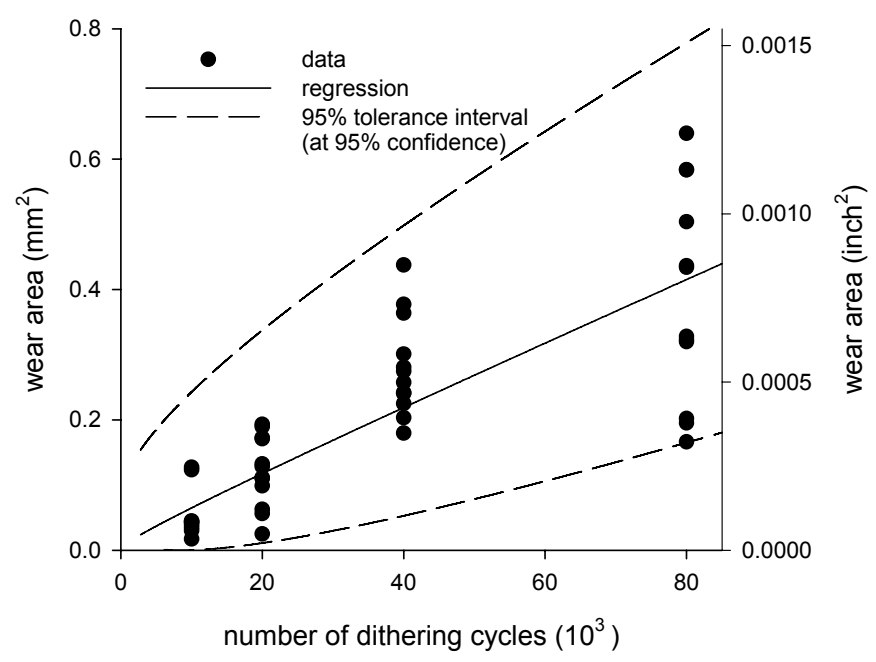

Figure 8.-Summary of wear area (or wear volume per unit face width) as a function of number of dithering cycles showing datapoints, regression model, and tolerance intervals. 


\section{Summary}

Discussions in support of space mechanism maintenance have highlighted the need for data to better understand the wear and behavior of mechanical components operated using perfluorinated polyether grease. To quantify wear rates for gears lubricated with such grease, a set of spur gear experiments were completed. The following results were obtained.

1. The visual appearance of the tested surface differed from tip to root, likely depending on the amounts of relative sliding and surface geometry details.

2. The visual appearance of the teeth surfaces were similar for all tests ranging from 20,000 to 80,000 total dithering cycles.

3. The wear rate was approximately $1.2 \mathrm{~nm}$ maximum wear depth per gear dithering cycle.

4. The wear rate for the grease lubricated gears of this study was on the order of 600 times greater than referenced data for oil lubricated gears operating in the mixed elastohydrodynamic lubrication regime.

5. Both the wear depth data and wear area data show a linear trend of wear accumulation for the full range of test cycles that were investigated.

6. The data showed a significant range of wear results for a given number of cycles. Statistical intervals were calculated to quantify the range of data one could expect for a large population of tests conducted in identical fashion.

\section{References}

1. Choy, F.K., Polyshchuk, V. and Zakrajsek, J.J., Handschuh, R.F. and Townsend, D.P., 1996, "Analysis of the Effects of Surface Pitting and Wear on the Vibration of a Gear Transmission System," Tribology International, 29, 77-83.

2. Mackaldener, M. Flodin, A. and Andersson, S., 2001, "Robust Noise Characteristics of Gears Due to their Applications, Manufacturing Errors and Wear," JSME International Conference on Motion and Power Transmission, MPT 2001, Fukuoka, Japan, 21-26.
3. Kuang, J.H. and Lin, A.D., 2001, "The Effect of Tooth Wear on the Vibration Spectrum of a Spur Gear Pair,' ASME Journal of Vibration and Acoustics, 123, 311-317.

4. Chen, Y. and Matubara, M., 2001, "Effect of Automatic Transmission Fluid on Pitting Fatigue Strength of Carburized Gears," JSME International Conference on Motion and Power Transmission, MPT 2001, Fukuoka, Japan, 151-156.

5. Shifeng, W. and Cheng, H.S., 1993, "Sliding Wear Calculation in Spur Gears," Journal of Tribology, 115, 493-503.

6. Flodin, A. and Andersson, S., 1997, "Simulation of Mild Wear in Spur Gears," Wear, 207, 123-128.

7. Flodin, A. and Andersson, S., 2000, "Simulation of Mild Wear in Helical Gears," Wear, 241, 123-128.

8. Flodin, A. and Andersson, S., 2001, "A Simplified Model for Wear Prediction in Helical Gears," Wear, 249, 285-292.

9. Bajpai, P., Kahraman, A., and Anderson, N., 2004, “ A Surface Wear Prediction Methodology for Parallel-Axis Gear Pairs," Journal of Tribology 126, 597-605.

10. Krantz, T. and Kahraman, A., 2004, “An Experimental Investigation of the Influence of the Lubricant Viscosity and Additives on Gear Wear," Tribology Transactions, 47, 138-148.

11. Archard, J.F., 1953, "Contact of Rubbing Flat Surfaces," Journal of Applied Physics, 24, 981-988.

12. Challen, J.M. and Oxley P.L.B., 1986, "Prediction of Archard's Wear Coefficient for Sliding Metallic Sliding Friction Assuming Low Cycle Fatigue Wear Mechanism," Wear, 111, 275-288.

13. Hall, P., et al., 2005 "Orbiter Rudder Speed Brake (R/SB) Gear Margins Technical Assessment Report," NASA Engineering and Safety Center RP-05-87.

14. Krantz, T. and Handschuh, R., 2004, "A Study of Spur Gears Lubricated With Grease-Observations from Seven Experiments," Proceedings of the $58^{\text {th }}$ Meeting of the Society for Machinery Failure Prevention Technology, Virginia Beach, VA, April 2004.

15. Hahn, G. and Meeker, W., 1991, Statistical Intervals-A Guide for Practitioners, John Wiley \& Sons, Inc., New York. 


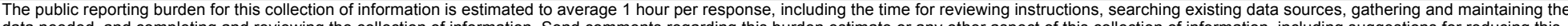

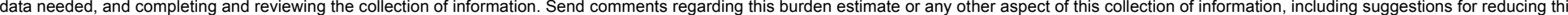

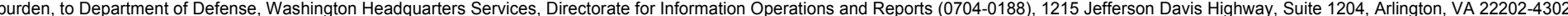

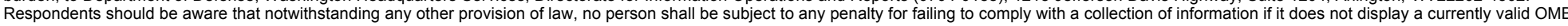
control number.

PLEASE DO NOT RETURN YOUR FORM TO THE ABOVE ADDRESS.

\section{REPORT DATE (DD-MM-YYYY) \\ 2. REPORT TYPE \\ 3. DATES COVERED (From - To)}

01-12-2007

Technical Memorandum

\section{TITLE AND SUBTITLE}

Wear of Spur Gears Having a Dithering Motion and Lubricated With a Perfluorinated

Polyether Grease

5a. CONTRACT NUMBER

5b. GRANT NUMBER

5c. PROGRAM ELEMENT NUMBER

6. AUTHOR(S)

Krantz, Timothy; Oswald, Fred; Handschuh, Robert

\section{5d. PROJECT NUMBER}

5e. TASK NUMBER

5f. WORK UNIT NUMBER

WBS 877868.02.07.03.01.01

8. PERFORMING ORGANIZATION REPORT NUMBER

E-16195

National Aeronautics and Space Administration

John H. Glenn Research Center at Lewis Field

Cleveland, Ohio 44135-3191

\section{SPONSORING/MONITORING AGENCY NAME(S) AND ADDRESS(ES)}

National Aeronautics and Space Administration

Washington, DC 20546-0001

10. SPONSORING/MONITORS ACRONYM(S)

NASA, ARL

11. SPONSORING/MONITORING REPORT NUMBER

NASA/TM-2007-215008; ARL-TR-4124

\section{DISTRIBUTION/AVAILABILITY STATEMENT}

Unclassified-Unlimited

Subject Category: 37

Available electronically at http://gltrs.grc.nasa.gov

This publication is available from the NASA Center for AeroSpace Information, 301-621-0390

\section{SUPPLEMENTARY NOTES}

\section{ABSTRACT}

Gear contact surface wear is one of the important failure modes for gear systems. Dedicated experiments are required to enable precise evaluations of gear wear for a particular application. The application of interest for this study required evaluation of wear of gears lubricated with a grade 2 perfluorinated polyether grease and having a dithering (rotation reversal) motion. Experiments were conducted using spur gears made from AISI 9310 steel. Wear was measured using a profilometer at test intervals encompassing 10,000 to 80,000 cycles of dithering motion. The test load level was $1.1 \mathrm{GPa}$ maximum Hertz contact stress at the pitch-line. The trend of total wear as a function of test cycles was linear, and the wear depth rate was approximately $1.2 \mathrm{~nm}$ maximum wear depth per gear dithering cycle. The observed wear rate was about 600 times greater than the wear rate for the same gears operated at high speed and lubricated with oil.

\section{SUBJECT TERMS}

Wear; Gears; Greases; Lubrication

\begin{tabular}{|c|c|c|c|c|}
\hline \multicolumn{3}{|c|}{ 16. SECURITY CLASSIFICATION OF: } & \multirow{2}{*}{$\begin{array}{l}\text { 17. LIMITATION OF } \\
\text { ABSTRACT } \\
\text { UU }\end{array}$} & \multirow{2}{*}{$\begin{array}{l}\text { 18. NUMBER } \\
\text { OF } \\
\text { PAGES } \\
13\end{array}$} \\
\hline $\begin{array}{l}\text { a. REPORT } \\
\text { U }\end{array}$ & $\begin{array}{l}\text { b. ABSTRACT } \\
U\end{array}$ & $\begin{array}{l}\text { c. THIS } \\
\text { PAGE } \\
\text { U }\end{array}$ & & \\
\hline
\end{tabular}

19a. NAME OF RESPONSIBLE PERSON
STI Help Desk (email:help@ @ sti.nasa.gov)
19b. TELEPHONE NUMBER (include area code)
301-621-0390

Standard Form 298 (Rev. 8-98) Prescribed by ANSI Std. Z39-18 

